\title{
Vehicle Hydrocarbons' Emission Characteristics Determined Using the Monte Carlo Method
}

\author{
Piotr Laskowski ${ }^{1}$ - Damian Zasina ${ }^{2,3}$. Magdalena Zimakowska-Laskowska ${ }^{2}$. Jarosław Zawadzki ${ }^{3}$. \\ Aleksander Warchałowski ${ }^{3}$
}

Received: 4 September 2017 / Accepted: 8 October 2018 / Published online: 26 October 2018

(C) The Author(s) 2018

\begin{abstract}
Hydrocarbons (HCs) are products of incomplete combustion process which can occur during operation of the internal combustion engines (Flagan and Seinfeld 1988; Wallington et al. Meteorologische Zeitschrift, 17(2), 109-116, 2008). Incomplete combustion process affects the fuel consumption and engine performance (Baskar and Senthilkumar Engineering Science and Technology, an International Journal, 19, 438-443, 2016; Rakopoulos and Giakoumis 2009) also the emission of unburned HCs affects the emissions of the other air pollutants (Jung et al. Journal of Environmental Sciences, 54, 2132, 2017; Wang et al. Journal of Environmental Sciences, 46, 28-37, 2016; Kerbachi et al. Energy Procedia, 136, 388-393, 2017). This paper presents the methodology for the investigation of $\mathrm{HC}$ amount emitted from internal combustion engines. It can be used for estimation of the emission factors, emissions from various vehicles and engine types, also carrying out the environmental impact assessment of various vehicles. The $\mathrm{HC}$ emission characteristics is defined as the dependency between the measured $\mathrm{HC}$ emissions (specific distance emission) and the vehicle's velocity. The Monte Carlo simulation allows determining the $\mathrm{HC}$ emission's characteristics from internal combustion engines. In the paper, five emission characteristics determined using the consecutive Monte Carlo simulations are given. In each case, the characteristic is fit using the 7th degree (order) polynomial regression. The goodness of fit is assessed using Ramsey's RESET test, and the RMSE. The authors find application of the proposed methodology in various types of the internal combustion engines to assess their environmental properties.
\end{abstract}

Keywords Air pollution $\cdot$ Emission $\cdot$ Light-duty vehicle $\cdot$ Semi-ignition engine $\cdot$ Monte Carlo simulation

\section{Introduction}

Road transport is the one of the most important sources of pollutants released into the air [10, 17]. Results given by Lelieveld et al. [36] indicate that the air pollution emitted from the land traffic has important contribution to the premature mortality, in both groups of countries: developed and

Damian Zasina

damian.zasina@kobize.pl

1 Department of Automotive and Construction Machinery Engineering, Warsaw University of Technology, Narbutta 84 St., Warsaw, Poland

2 Institute of Environmental Protection-NRI, NECD, Chmielna 132/134 St., Warsaw, Poland

3 Faculty of Building Services, Hydro and Environmental Engineering, Warsaw University of Technology, Nowowiejska St. 20, Warsaw, Poland developing. An analysis given by Dedoussi and Barrett [13] highlights that the road transportation sector has significant contribution to the exposure to $\mathrm{PM}_{2.5}$ particulates, and they are in $29 \%$ the result of the nitric oxides' emission and in 33\%-usage of the ammonia in after-treatment technologies.

The number of intensive studies on the road transportation sector's environmental effects is also a result of the recent industrial affair commonly called Dieselgate $[3,6,8]$. Scientific investigations started to focus not only on the context of the air quality and health (e.g., [22, 23, 33, 57]), but also at the road transportation's emission limitation problems [16], and at the issues associated with environmental properties of the internal combustion engines [51].

Environmental properties of the internal combustion engines are not necessarily associated with the road transportation. In a broader context, studies on the marine internal combustion engines are devoted to the nitric and sulphuric oxides primarily $[9,29,35]$; however, the methodology 
based on the emission characteristics, presented in this paper, does not depend on the selected air pollutant.

The emission of unburned HCs can be taken into consideration as the engine's combustion performance indicator. During the incomplete combustion process, the $\mathrm{HC}$ emission affects the emissions of other pollutants, especially ultrafine particles and nitric oxides [28, 30, 56]. On the contrary to the nitric oxides, carbon monoxide or soot, the increase of the $\mathrm{HC}$ emission is observed also during the deceleration [28, 45]. Moreover, results given in [1, 58] and [55] show that the driving in congestion (urban peak) results with significant increase of $\mathrm{HC}$ emission. The HCs released into the air can cause negative health effects and also contributes to the ground-level ozone concentration or smog $[37,41]$.

Presented results find the transportation sector significant in the context of air quality and human health impact. More accurate determination of the $\mathrm{HC}$ emissions from this sector can help to carry out the detailed quantitative assessment of the air emission impact taking into account the negative health effects of smog episodes.

\section{Materials and Methods}

The emission is usually estimated using two variables: 'emission factor' and 'activity of the emission source' $[19,47,48,52]$. In case of the road transportation sector, the emission factor is the average emission of pollutant released into the air as a result of driving the particular distance or combustion of the particular amount of fuel. The $\mathrm{HC}$ emission inventory from the vehicles is determined as follows:

$E_{\mathrm{HC}}=\sum_{i, j, k}\left(E F_{\mathrm{HC}, j, k} \times A_{j, k}\right)$,

where: $E_{\mathrm{HC}}$-emission of hydrocarbons $[\mathrm{g}] ; E F-$ emission factor $\left[\mathrm{g} \cdot \mathrm{km}^{-1}\right]$; $i$-engine performance, e.g. accordingly to the European emission standards; $j-$ emission source (vehicle type: passenger car, light-duty vehicle, hard-duty vehicle, machinery, and other); $k$-fuel type (e.g. gasoline, diesel oil, $\mathrm{CNG}$ ); $A_{j, k}$-activity for the emission source, distance-driven $j[\mathrm{~km}]$.

Emission factors are various and depend on the technology, year of production, style of driving and many other variables. It causes that the emission factors are widely applied to assess the engines' environmental properties.

\subsection{Specific Distance Pollutant Emission}

Apart from emission factors (1), the air pollutants' emissions can be also used for determining the environmental impact of vehicles. The measured value $\hat{E}$ (see Eq. 2) is known as the specific distance pollutant emission (SPDE). SPDE, defined as the averaged emission per the vehicle's mileage, is obtained in the laboratory by measuring the real time emission using the exhaust gases' analyzer. The 'emission' is defined as the total mass of particular pollutant released into the air [12].

Mathematically, SPDE (further notation: $\hat{b}$ ) is a derivative of emission with respect to the distance travelled by the vehicle. The distance travelled is measured using the chassis dynamometer. SPDE is associated with the particular distance associated with the driving cycle (see Section 2.3).

$\hat{b}=\frac{\hat{E}}{\hat{s}}=\frac{V_{\text {mix }} \cdot Q_{\mathrm{HC}} \cdot k_{\mathrm{H}} \cdot C_{\mathrm{HC}} \cdot 10^{-9}}{s}$,

where: $\{\hat{y}$ —average value; $\hat{E}$-emission, measured by exhaust gas analyzer $[\mathrm{g}] ; s$-vehicle's distance measured by the chassis dynamometer $[\mathrm{km}] ; V_{\operatorname{mix}}$-volume of the diluted exhaust gas $\left[\mathrm{m}^{3} /\right.$ test $]$, corrected to the standard conditions $(T=293 \mathrm{~K}, p=101.33 \mathrm{kPa}) ; Q_{\mathrm{HC}}$-density of the analysed HCs at standard conditions $\left[\mathrm{kg} / \mathrm{m}^{3}\right] ; k_{\mathrm{H}}-$ humidity correction factor [dimensionless], for HCs $k_{\mathrm{H}}=$ 1; $C_{\mathrm{HC}}$-concentration of the $\mathrm{HCs}$ in the diluted exhaust gas measured by the exhaust gas analyzer and corrected by the amount of HCs contained in the dilution air [ppm].

Parameter $\hat{b}$ can be also expressed as a dynamic value (variable over time) depending on the engine operating state processes which is usually characterized by (operator notation used):

- engine load- $M_{e}(t)$,

- engine speed- $n(t)$,

- engine thermal state- $T_{S}(t)$, expressed as the set of engine parts' temperatures and factors operating on its systems such as coolant and lubricating oil, and

- environmental conditions-G(t):

$$
\begin{aligned}
b(t) & =\Xi_{M}\left[M_{e}(t), n(t), T_{S}(t), G(t)\right] \\
& =\Xi_{v}\left[v(t), A(t), T_{S}(t), G(t)\right],
\end{aligned}
$$

where: $\Xi_{M}$-operator using the engine load; $\boldsymbol{\Xi}_{v}$ 一operator using the vehicle's velocity $v(t) ; A(t)$-matrix which contains information about vehicle motion resistance connected with the shape and other properties of the surface [7].

The SPDE $(\hat{b})$ can be then expressed together with the time series of the vehicle's velocity ( $\hat{b}$ vs. $\hat{v}$ ). This kind of dependency is defined as emission characteristics.

\subsection{Laboratory Equipment}

Empirical tests are conducted on a Citroën Berlingo light-duty vehicle, equipped with a semi-ignition engine. The vehicle's velocity is investigated using a chassis 
dynamometer EMDY 48 (Schenck-Komeg, one roller of $48^{\prime \prime}$ diameter) [50], and HC emission-using exhaust gases analyzer FIA-725A, MEXA 7200 (Horiba) [25]. The measurements took place at the Automotive Industry Institute in Warsaw. Equipment used in the tests was in accordance with the requirements of the Directive of the European Parliament and Council on vehicles homologation testing [15] also the metrological and technical requirements for instruments measuring vehicle exhaust emissions [27]. Among various types of tests, e.g. FTP 75, HWFET, Stop and Go and Autobahn [14, 18], the chosen procedure is in line with the Rule No. 83 ECE [54].

\subsection{The NEDC Driving Cycle}

The pseudo-random road traffic conditions are modelled in the form of a stochastic process $v(t)$ which is established as the NEDC driving cycle (Fig. 1) [2, 40, 42, 54].

The NEDC driving cycle is a version of the former driving test named EC+EUDC [38, 45, 53]. The last update of the cycle took place in 1997. The NEDC driving cycle is elaborated to simulate the statistically average use of vehicle in Europe. It consists of the two parts from which EC simulates urban driving, and EUDC - extra urban. Before the test, the vehicle is allowed to soak for at least $6 \mathrm{~h}$ at a test temperature of $20-30{ }^{\circ} \mathrm{C}$. It is then started and allowed to idle for $40 \mathrm{~s}$. The beginning of the sampling starts after $40 \mathrm{~s}$ from the start of the cycle. The length of the cycle is $1,220 \mathrm{~s}$ on the distance of $11,007 \mathrm{~m}$, including the idle period. Average vehicle's velocity is $9 \mathrm{~m} / \mathrm{s}(32.5[\mathrm{~km} / \mathrm{h}])$, and maximal-33 m/s $(120 \mathrm{~km} / \mathrm{h})$. In 2000, the idling period has been eliminated, i.e. engine starts at $0 \mathrm{~s}$ and the emission sampling begins at the same time. This modified cold-start procedure is referred to as the New European Driving Cycle (NEDC).

\subsection{Stochastic Model}

The multidimensional stochastic process of phenomena accompanying the operation of a vehicle $Y(t)$ applies to the $\mathrm{HC}$ emission and fuel consumption primarily:

$Y(t)=\left[E_{\mathrm{HC}}, G_{\mathrm{f}}\right]^{\top}$,

where: $E_{\mathrm{HC}}$-intensity of $\mathrm{HC}$ emissions; $G_{\mathrm{f}}$-intensity of fuel consumption.

Considering processes $v(t)$ and $Y(t)$ as functions of the time, it can be considered that the notations $v(t)$ and $Y(t)$ are equivalent. Assuming the ergodicity of $v(t)$ and $Y(t)$, means:

$\lim _{\tau \rightarrow \infty} E\left\{\left[\frac{1}{\tau} \int_{t_{0}}^{t_{0}+\tau}\{\cdot\} d t-\mu_{\{\cdot\}}\right]^{2}\right\}=0$,

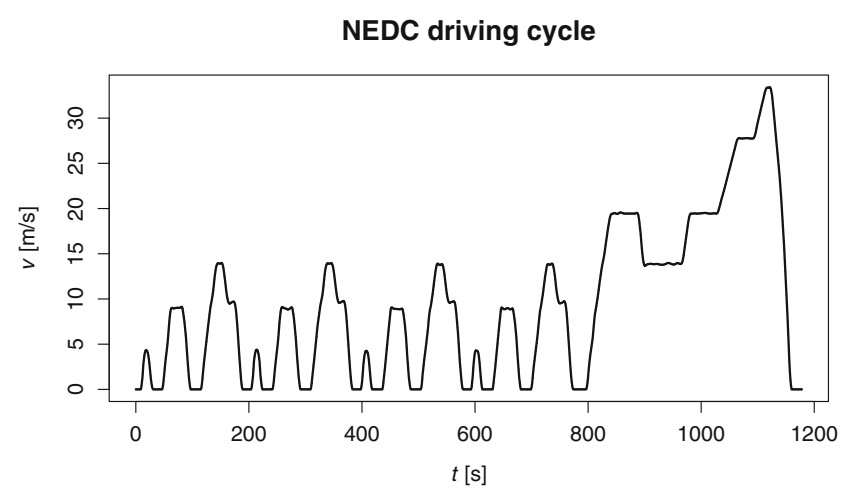

Fig. 1 The NEDC driving cycle

where: $\{\cdot\}-v(t)$ or $Y(t) ; \mu_{\{\cdot\}}$-expected value of $v(t)$ or $Y(t)$ (constant); $t_{0}$ - start of averaging process; $\tau$-length of the averaging process.

There is possible to determine their average values $(\hat{v}$ and $\hat{Y})$ in the expected time frame $\left(t_{\alpha}, t_{\omega}\right)$, as below:

$\hat{v}\left(t_{\alpha}, t_{\omega}\right)=\frac{1}{t_{\omega}-t_{\alpha}} \int_{t_{\alpha}}^{t_{\omega}} v(t) d t$,

$\hat{Y}\left(t_{\alpha}, t_{\omega}\right)=\frac{1}{t_{\omega}-t_{\alpha}} \int_{t_{\alpha}}^{t_{\omega}} Y(t) d t$.

$\operatorname{SPDE}(\hat{b})$ is defined as the ratio of particular pollutant's emission concentration and the vehicle's velocity. Thus, the average specific distance pollutant emissions are expressed as follows:

$\hat{b}=\frac{\hat{E}\left(t_{\alpha}, t_{\omega}\right)}{\hat{v}\left(t_{\alpha}, t_{\omega}\right)}$.

Considering the average specific distance pollutant emissions as a function of average velocity as well as the time of the start and finish of the averaging process:

$\hat{b}=f\left(\hat{v}\left(t_{\alpha}, t_{\omega}\right), t_{\alpha}, t_{\omega}\right)$.

Assuming that the $t$ is the random variable, in particular, $t_{\alpha}$ and $t_{\omega}$, then the $\operatorname{SPDE}(\hat{b})$ should be treated as a random function. The dependency $\hat{b}$ vs. $\hat{v}$ is simultaneously characteristic of the $\mathrm{HC}$ emission process.

Monte Carlo simulation (e.g. [24, 39, 43]) gives the possibility of determining the stochastic characteristics of vehicle pollutant emissions expressed as the form of dependence between $\hat{b}$ and the average vehicle velocity $\hat{v}$. Similarly, it is possible to consider one-dimensional characteristic dependencies between the SPDE and other values, e.g. the average value of the module of acceleration or the average value of the module of the product of velocity and acceleration. There is also a possibility of determining multidimensional characteristics of air pollutants' emissions. 
A fundamental quality of the proposed method for determining characteristics is the ability to obtain information about the examined object on the basis of a single implementation of the stochastic process. Thus, the Monte Carlo method has been applied in line with the initial, historical intention of its creators [39].

Registration of the processes of pollutant emission concentrations was processed digitally, eliminating significant errors and conducting low-pass filtration. The GolaySavitzky filter [49] was used in filtration, with the following averaging parameters: two-sided use of two points and a second degree approximating polynomial (smoothing).

\subsection{Quantitative Assessment}

Characteristics are fitted to the $\hat{b}$ vs. $\hat{v}$ dependency using the polynomial regression for each from five independent Monte Carlo simulations. Influential observations are rejected from the models if their Cook's distances exceeded 2. Cook's distances $[5,11,21]$ are calculated using procedure implemented in statistical language $R$ [44]. The correctness of the analytical model forms is checked using Ramsey's RESET test $[32,46]$ implemented in the lmtest library [26].

To carry out a quantitative assessment of all SPDE simulations, the root mean square error $(R M S E)$ is calculated:

$R M S E=\sqrt{\frac{1}{n} \sum_{i=1}^{n}\left(b_{i}\left(\hat{v}_{i}\right)-\hat{b}\left(\hat{v}_{i}\right)\right)^{2}}$,

where: $R M S E$ - root mean square error of the $\hat{b} ; i$-the number of speed's averagings; $\hat{v}_{i}$ - the $i$-th averaged speed; $\hat{b}$, the average SPDE value obtained from the one series series.

\section{Results and Discussion}

Figure 2 shows the processed HC emission concentration processes using Golay-Savitzky low-pass filtration [49]. The emission is automatically calculated by registering the volume of air flow used by the engine (2). The processes of the air flow through the engine is subject to the same digital processing procedures as the pollutant emission concentration processes.

The registered vehicle's velocity processes as well as the $\mathrm{HC}$ emission concentrations are used to determine pollutant emission characteristics.

The determined characteristics using five consecutive Monte Carlo simulations (MC_1, MC_2, MC_3, MC_4, and MC_5) presented in the figures below (Figs. 3, 4, 5, 6 and 7). The figures show the original series of the lab measurements (grey points) with the determined $\mathrm{HC}$

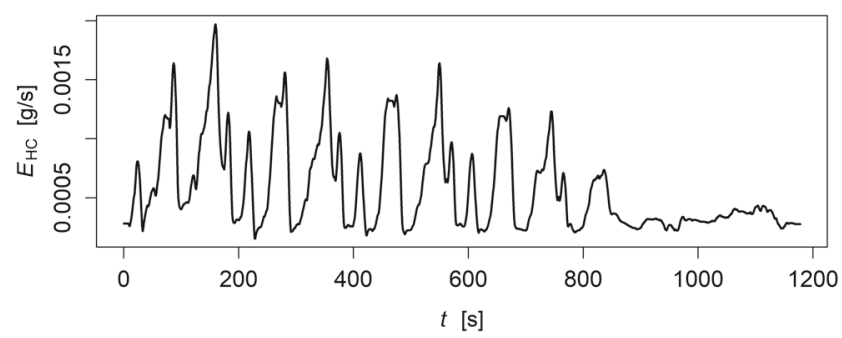

Fig. 2 The time series of the hydrocarbons' emission intensity $E_{\mathrm{HC}}[\mathrm{g} / \mathrm{s}]$

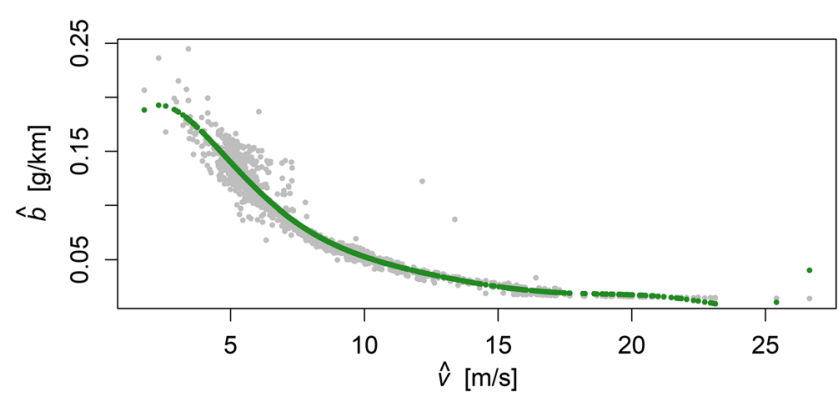

Fig. 3 Simulation 1 (MC_1). $\hat{b}[\mathrm{~g} / \mathrm{km}])$ vs. $\hat{v}[\mathrm{~m} / \mathrm{s}]$. Characteristics added

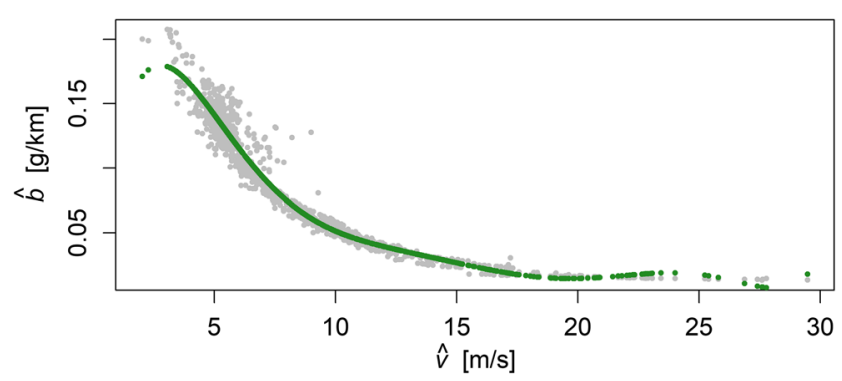

Fig. 4 Simulation 2 (MC_2). $\hat{b}[\mathrm{~g} / \mathrm{km}])$ vs. $\hat{v}[\mathrm{~m} / \mathrm{s}]$. Characteristics added

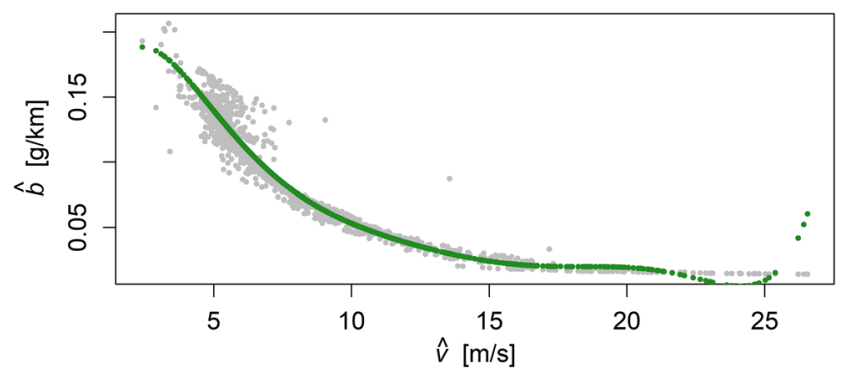

Fig. 5 Simulation 3 (MC_3). $\hat{b}[\mathrm{~g} / \mathrm{km}])$ vs. $\hat{v}[\mathrm{~m} / \mathrm{s}]$. Characteristics added 


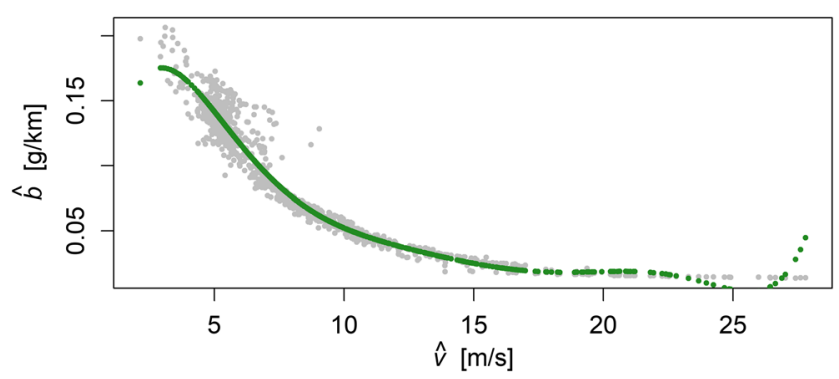

Fig. 6 Simulation 4 (MC_4). $\hat{b}$ [g/km]) vs. $\hat{v}[\mathrm{~m} / \mathrm{s}]$. Characteristics added

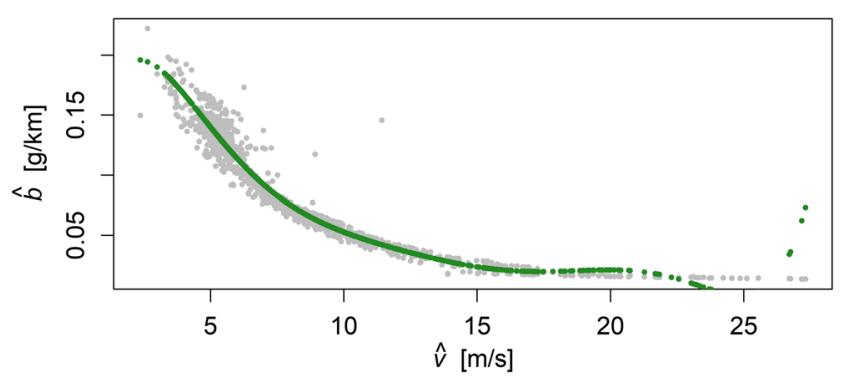

Fig. 7 Simulation 5 (MC_5). $\hat{b}$ [g/km]) vs. $\hat{v}[\mathrm{~m} / \mathrm{s}]$. Characteristics added

Table 1 The qualitative assessment of the Monte Carlo simulations of the $\hat{b}$ vs. $\hat{v}$ dependency

\begin{tabular}{llll}
\hline Simulation & $R^{2}$ & $R M S E$ & RESET (p-value) \\
\hline MC_1 & 0.9092 & 0.0114 & 0.5557 \\
MC_2 & 0.9303 & 0.0102 & 0.0329 \\
MC_3 & 0.8932 & 0.0111 & $8.022 \cdot 10^{-9}$ \\
MC_4 & 0.9260 & 0.0107 & 0.2040 \\
MC_5 & 0.9058 & 0.0106 & $9.06 \cdot 10^{-13}$ \\
\hline
\end{tabular}

For each simulation is applied the polynomial fit of 7th degree (order). Ramsey RESET test's $p$ value indicates the correctness of fit emission characteristics (green line). The goodness of fit is performed using the coefficient of determination $\left(R^{2}\right)$, $R M S E$, and the $p$ value of the Ramsey's RESET Test. They are presented in Table 1. The parameters of the determined characteristics are given in Table 2.

Repeatability and reproducibility is characteristic for the Monte Carlo simulation. Basing on previously gained knowledge [7, 31, 34] is possible to conclude about the process. In the case of HCs released from the light-duty vehicles' semi-ignition engines, the characteristic is the significant characteristic's decrease along with the increase of the average vehicle velocities (Figs. 3-7). Obtained results confirm the finding given in [1] and [45] on nontypical behavior of the HCs in comparison to the another pollutants (e.g. nitric or sulphuric oxides).

\section{Conclusions and Outlook}

Characteristics of pollutant emissions in the form of a dependences between specific distance emissions and average velocity are a valuable source of information about the environmental properties of vehicles in their operating conditions. The characteristics significantly facilitate the combustion process performance and help to determine emission factors in various operational states of the internal combustion engines.

Without an awareness of these characteristics it is not possible to balance pollutant emissions for road traffic, and thus also assess the negative impact of the road transportation on the environment and human health.

The methodology presented in this paper uses the fixed function of speed over time together with the measured time series of the pollutant released into the air. That means the methodology is not dependent on the measured pollutant nor the combusted fuel. It can be considered for application to various types of internal combustion engines, including marine or aeronautical.

The potential application for the proposed method is broad. It can be used to study many objects, not only technical ones, for which the co-dependence of processes
Table 2 The parameters of obtained emission characteristics ( $\hat{b}$ vs. $\hat{v}$ regressions)

\begin{tabular}{lllllllll}
\hline Sim. & $\beta_{0}$ & $\beta_{1}$ & $\beta_{2}$ & $\beta_{3}$ & $\beta_{4}$ & $\beta_{5}$ & \multicolumn{1}{l}{$\beta_{6}$} & $\beta_{7}$ \\
\hline MC_1 & 0.0959 & -1.3791 & 0.7036 & -0.0731 & 0.0923 & 0.1650 & -0.0358 & 0.0923 \\
MC_2 & 0.0957 & -1.3203 & 0.7309 & -0.1817 & 0.0554 & 0.1486 & -0.0852 & 0.1144 \\
MC_3 & 0.0923 & -1.3611 & 0.7225 & -0.0997 & 0.1272 & 0.1795 & 0.0345 & 0.1044 \\
MC_4 & 0.0932 & -1.2747 & 0.7004 & -0.1505 & 0.0364 & 0.1737 & -0.0388 & 0.1131 \\
MC_5 & 0.0946 & -1.3514 & 0.7404 & -0.1268 & 0.0859 & 0.1805 & -0.0191 & 0.1277 \\
\hline
\end{tabular}

Polynomial fit in form: $\hat{b}_{i}=\beta_{0}+\sum_{n=1}^{k=7} \beta_{n} \cdot\left(\hat{v}_{i}\right)^{n}$ 
describing the object is characteristic and expressed as the postulated determination or confirmed correlation.

The emission characteristics elaborated with using the collected data are determined by application of the Monte Carlo method and the polynomial regression. The repeatability and reproducibility of the presented methodology can be easily found by analyzing their shapes-decreasing along with the increasing velocity. The significant increases of the characteristics at the right tails can be explained with the expected $\mathrm{HC}$ emission increase during the engine clutch [1].

The proposed methodology is characterized by the low sensitivity to various pseudo-random conditions occurring during carrying out the experiments. That means the determined characteristics do not depend on the applied methodology. This result of the simulation research confirms the effectiveness of this method in determining characteristics of the emission produced by car engines.

It is possible to significantly expand the test programme to encompass other properties of the considered stochastic process.

Open Access This article is distributed under the terms of the Creative Commons Attribution 4.0 International License (http:// creativecommons.org/licenses/by/4.0/), which permits unrestricted use, distribution, and reproduction in any medium, provided you give appropriate credit to the original author(s) and the source, provide a link to the Creative Commons license, and indicate if changes were made.

\section{References}

1. Andrzejewski, M. (2013). Uncertainties in emission inventories. Ph.D. thesis, Poznan University of Technology. http://repozytorium. http://repozytorium.put.poznan.pl/Content/285883/Maciej_Andrz ejewski_Wplyw_stylu_jazdy_kierowcy_na_zuzycie_paliwa_i_emisje _substancji_szkodliwych_w_spalinach.pdf. [in Polish].

2. Barlow, T., Latham, S., McCrae, I., Boulter, P. (2009). A reference book of driving cycles for use in the measurement of road vehicle emissions. Tech. rep., TRL Limited. https://www.gov.uk/ government/uploads/system/uploads/attachment_data/file/4247/ ppr-354.pdf. Published Project Report PPR354.

3. Barrett, S., Speth, R., Eastham, S., Dedoussi, I., Ashok, A., Malina, R., Keith, D. (2015). Impact of the Volkswagen emissions control defeat device on US public health. Environmental Research Letters, 10, 1-10. https://doi.org/10.1088/1748-9326/ 10/11/114005.

4. Baskar, P., \& Senthilkumar, A. (2016). Effects of oxygen enriched combustion on pollution and performance characteristics of a diesel engine. Engineering Science and Technology, an International Journal, 19, 438-443. https://doi.org/10.1016/j.jestch. 2015.08.011.

5. Belsley, D., Kuh, E., Welsch, R. (1980). Regression diagnostics: identifying influential data and sources of collinearity. New York: Wiley. https://doi.org/10.1002/0471725153.

6. Brand, C. (2016). Beyond 'Dieselgate': implications of unaccounted and future air pollutant emissions and energy use for cars in the United Kingdom. Energy Policy (97), 1-12. https://doi.org/ 10.1016/j.enpol.2016.06.036.

7. Chłopek, Z., \& Laskowski, P. (2009). Pollutant emission characteristics determined using the Monte Carlo Metod. Maintenance and Reliability, 2, 42-51. http://www.ein.org.pl/sites/default/files/ 2009-02-06.pdf. Accessed: 2 Aug 2016.

8. Chossière, G., Malina, R., Ashok, A., Dedoussi, I., Eastham, S., Speth, R., Barrett, S. (2017). Public health impacts of excess $\mathrm{NO}_{\mathrm{X}}$ emissions from Volkswagen diesel passenger vehicles in Germany. Environmental Research Letters, 12, 1-14. https://doi.org/10.1088/1748-9326/aa5987.

9. Chybowski, L., Laskowski, R., Gawdzińska, K. (2015). An overview of systems supplying water into the combustion chamber of diesel engines to decrease the amount of nitrogen oxides in exhaust gas. Journal of Marine Science and Technology, 20, 393405. https://doi.org/10.1007/s00773-015-0303-8.

10. Colvile, R., Hutchinson, E., Mindell, J., Warren, R. (2001). The transport sector as a source of air pollution. Atmospheric Environment, 35, 1537-1565. https://doi.org/10.1016/S1352-2310 (00)00551-3.

11. Cook, R., \& Weisberg, S. (1980). Residuals and influence in regression. New York: Chapman and Hall.

12. de Haan, P., \& Keller, M. (2004). Modelling fuel consumption and pollutant emissions based on real-world driving patterns: the hbefa approach. International Journal of Environment and Pollution, 22(3), 240-258. https://doi.org/10.1504/IJEP.2004.005538.

13. Dedoussi, I., \& Barrett, S. (2014). Air pollution and early deaths in the United States. Part II: attribution of $\mathrm{PM}_{2.5}$ exposure to emissions species, time, location and sector. Atmospheric Environment, 99, 610-617. https://doi.org/10.1016/j.atmosenv.2014.10. 033.

14. diesel.net: Emission test cycles. https://www.dieselnet.com/ standards/cycles/index.php. Accessed: 19 Aug 2017.

15. Directive 2007/46/EC of the European Parliament and of the Council of 5 September 2007 establishing a framework for the approval of motor vehicles and their trailers and of systems, c.: http://eur-lex.europa.eu/legal-content/EN/ALL/?uri=CELEX.

16. Dzikuć, M., Adamczyk, J., Piwowar, A. (2017). Problems associated with the emissions limitations from road transport in the Lubuskie Province (Poland). Atmospheric Environment, 160, 1-8. https://doi.org/10.1016/j.atmosenv.2017.04.011.

17. EEA. (2013). Understanding pollutant emissions from Europe's cities. Highlights from the EU Air Implementation Pilot project. Copenhagen: EEA. https://doi.org/10.2800/51246.

18. Esteves-Booth, A., Muneer, T., Kubie, J., Kirby, H. (2002). A review of vehicular emission models and driving cycles. Proceedings of the Institution of Mechanical Engineers. Part C: J Mechanical Engineering Science, 216, 777-797. https://doi.org/10.1243/ 09544060260171429.

19. Fameli, K.M., \& Assimakopoulos, V. (2016). The new open Flexible Emission Inventory for Greece and the Greater Athens Area (FEI-GREGAA): account of pollutant sources and their importance from 2006 to 2012. Atmospheric Environment, 137, 17-37. https://doi.org/10.1016/j.atmosenv.2016.04.004.

20. Flagan, R., \& Seinfeld, J. (1988). Fundamentals of air pollution engineering. Englewood: Prentice Hall.

21. Fox, J. (1997). Applied regression, linear models, and related methods. Newbury Park: Sage.

22. Gregory, D., McLaughlin, O., Mullender, S., Sundararajah, N. (2016). Urban Air Quality Study. London Forum for Science and Policy Briefing paper.

23. Gulia, S., Shiva Nagendra, S., Khare, M., Khanna, I. (2015). Urban air quality management-a review. Atmospheric Pollution Research, 6, 286-304. https://doi.org/10.5094/APR.2015.033. 
24. Harrison, R. (2010). Introduction to Monte Carlo simulation. AIP Conference Proceedings, 1204(1), 17-21. https://doi.org/10. 1063/1.3295638.

25. HORIBA: MEXA-7000 Version 3 (2017). http://www.horiba.com/ automotive-test-systems/products/emission-measurement-systems/ analytical-systems/standard-emissions/details/mexa-7000-version3-930/. Accessed: 20 Aug 2017.

26. Hothorn, T., Zeileis, A., Farebrother, R., Cummins, C., Millo, G., Mitchell, D. (2017). Testing linear regression models. https:// CRAN.R-project.org/package $=$ lmtest.

27. International Organization for Standardization: Instruments for measuring vehicle exhaust emissions-metrological and technical requirements; Metrological control and performance tests (2009). ISO/PAS 3930:2009 (OIML R99-1 \& -2:2008).

28. Jung, S., Lim, J., Kwon, S., Jeon, S., Kim, J., Lee, J., Kim, S. (2017). Characterization of particulate matter from diesel passenger cars tested on chassis dynamometers. Journal of Environmental Sciences, 54, 21-32. https://doi.org/10.1016/j.jes.2016.01. 035 .

29. Keiji, S., \& Toshiyuki, K. (2016). Eco-shipping project with a speed planning system for japanese coastal vessels. Scientific Journals of the Maritime University of Szczecin, 46(118), 147154. https://doi.org/10.17402/132.

30. Kerbachi, R., Chikhi, S., Boughedaoui, M. (2017). Development of real exhaust emission from passenger cars in Algeria by using on-board measurement. Energy Procedia, 136, 388-393. https://doi.org/10.1016/j.egypro.2017.10.268.

31. Knörr, W., Hausberger, S., Helms, H., Lambrecht, U., Keller, M., Steven, H. (2011). Weiterentwicklung der Emissionsfaktoren für das Handbuch für Emissionsfaktoren (HBEFA). http://www.bmub.bund.de/fileadmin/Daten_BMU/Pools/ Forschungsdatenbank/fkz_3709_52_142_emissionsfaktoren_bf. pdf. Accessed: 20 Aug 2017.

32. Krämer, W., \& Sonnberger, H. (1986). The linear regression model under test. Physica-Verlag HD. https://doi.org/10.1007/ 978-3-642-95876-2. http://www.jstor.org/stable/2984219.

33. Krzyżanowski, M., Kuna-Dibbert, B., \& Schneider, J. (Eds.) (2005). Health effects of transport-related air pollution. http:// www.euro.who.int/__data/assets/pdf_file/0006/74715/E86650.pdf. Accessed: 20 Aug 2017.

34. Laskowski, P. (2015). Wyznaczanie charakterystyk emisji zanieczyszczeń w przypadkowych stanach pracy samochodowych silników spalinowych. Ph.D. thesis, Warsaw University of Technology [in Polish].

35. Laskowski, R., Chybowski, L., Gawdzińska, K. (2015). An engine room simulator as a tool for environmental education of marine engineers. New Contributions in Information Systems and Technologies, 354, 311-322. https://doi.org/10.1007/978-3-31916528-8_29.

36. Lelieveld, J., Evans, J., Fnais, M., Giannadaki, D., Pozzer, A. (2015). The contribution of outdoor air pollution sources to premature mortality on a global scale. Nature, 525, 367-374. https://doi.org/10.1038/nature15371.

37. Macias, J., Martínez, H., Unal, A. Bus Technology Meta-analysis. http://www.wrirosscities.org/sites/default/files/Bus-TechnologyMeta-Analysis.pdf. 89th TRB 2010 Annual Meeting, Washington, D.C., January 10-14, 2010.

38. MECA: Vehicle emission standards: Europe. http://www.meca. org/galleries/files/European_Regs06.pdf. Accessed: 3 July 2018.

39. Metropolis, N., \& Ulam, S. (1949). The Monte Carlo Method. Journal of the American Statistical Association, 44(247), 335341. https://doi.org/10.2307/2280232.

40. Nyberg, P., Frisk, E., Nielsen, L. (2014). Generation of equivalent driving cycles using Markov Chains and mean tractive force com- ponents. http://www.vehicular.isy.liu.se/Publications/Articles/ IFACWC_14_PN_EF_LN.pdf. 19th IFAC World Congress, August 24-29, 2014, Cape Town, South Africa. Accessed: 2 Aug 2016.

41. Nylund, N.O., Erkkilä, K., Lappi, M., Ikonen, M. Transit Bus Emission Study: Comparison of Emissions from Diesel and Natural Gas Buses. http://www.vtt.fi/inf/julkaisut/muut/2004/ TransitBusEmission.pdf. VTT Processes.

42. Pacheco, A., Martinsa, M.E., Zhao, H. (2013). New European Drive Cycle (NEDC) simulation of a passenger car with a HCCI engine: emissions and fuel consumption results. Fuel, 111, 733739. https://doi.org/10.1016/j.fuel.2013.03.060.

43. Paxton, P., Curran, P., Bollen, K., Kirby, J., Chen, F. (2001). Monte Carlo experiments: design and implementation. Structural Equation Modeling: A Multidisciplinary Journal, 8(2), 287-312. https://doi.org/10.1207/S15328007SEM0802_7.

44. R Core Team. (2016). R: a language and environment for statistical computing. Vienna: $\mathrm{R}$ Foundation for Statistical Computing. https://www.R-project.org/.

45. Rakopoulos, C., \& Giakoumis, E. (2009). Diesel Engine Transient Operation. Springer. https://doi.org/10.1007/978-1-84882375-4.

46. Ramsey, J. (1969). Tests for specification error in classical linear least squares regression analysis. Journal of the Royal Statistical Society Series B, 31(2), 350-371. http://www.jstor.org/stable/ 2984219.

47. Réquia, W. Jr., Koutrakis, P., Roig, H. (2015). Spatial distribution of vehicle emission inventories in the Federal District, Brazil. Atmospheric Environment, 112, 32-39. https://doi.org/10.1016/j. atmosenv.2015.04.029.

48. Resetar, M., Pejic, G., Lulic, Z. (2017). Road transport emissions of passenger cars in the republic of croatia. In Digital proceedings of the 8th European combustion meeting (pp. 25532558). Croatia: Dubrovnik. https://bib.irb.hr/datoteka/878082. ECM2017_M_603.pdf. Accessed: 1 Sep 2017.

49. Savitzky, A., \& Golay, M. (1964). Smoothing and differentiation of data by simplified least squares procedures. Analytical Chemistry, 36(8), 1627-1639. https://doi.org/10.1021/ac60214a047.

50. SCHENCK: Technical Specification Eddy-Current Dynamometer W Series (2001). http://www.jadsys.com/uploads/5/7/4/2/ 57421049/jad_schenk_eddy_current_dynamometer.pdf. Accessed: 20 Aug 2017.

51. Sivalakshmi, S., Lenin, V., Hari Prakash, C. (2016). Investigation on the combustion, performance and emissions of a diesel engine fuelled by biodiesel and its blends with different oxygenated organic compounds. International Journal of Ambient Energy, 37(5), 513-519. https://doi.org/10.1080/01430750.2015. 1023465.

52. Song, X., Hao, Y., Zhang, C., Peng, J., Zhu, X. (2016). Vehicular emission trends in the Pan-Yangtze River Delta in China between 1999 and 2013. Journal of Cleaner Production, 137, 1045-1054. https://doi.org/10.1016/j.jclepro.2016.07.197.

53. TRANSPORTPOLICY: https://www.transportpolicy.net/standard/ eu-light-duty-new-european-driving-cycle/. Accessed: 3 Jul 2018.

54. UN ECE (2011). Regulation No. 83 of the Economic Commission for Europe of the United Nations (UN/ECE)-Uniform provisions concerning the approval of vehicles with regard to the emission of pollutants according to engine fuel requirements. https://www.unece.org/fileadmin/DAM/trans/main/wp29/ wp29regs/r083r4e.pdf. Accessed: 19 Aug 2017.

55. Wallington, T., Sullivan, J., Hurley, M. (2008). Emissions of $\mathrm{CO}_{2}$, $\mathrm{CO}, \mathrm{NO}_{\mathrm{X}}, \mathrm{HC}, \mathrm{PM}, \mathrm{HFC}-134 \mathrm{a}, \mathrm{N}_{2} \mathrm{O}$ and $\mathrm{CH}_{4}$ from the global light duty vehicle fleet. Meteorologische Zeitschrift, 17(2), 109116. https://doi.org/10.1127/0941-2948/2008/0275. 
56. Wang, G., Cheng, S., Lang, J., Li, S., Tian, L. (2016). Onboard measurements of gaseous pollutant emission characteristics under real driving conditions from light-duty diesel vehicles in Chinese cities. Journal of Environmental Sciences, 46, 28-37. https://doi.org/10.1016/j.jes.2015.09.021.

57. White, L., Boocock, C., Cooper, J., Miles, A., Mills, S. (2016). Urban air quality study. https://www.concawe.eu/wp-content/ uploads/2017/01/rpt_16-11.pdf. Report no. 11/16. Accessed: 20 Aug 2017.

58. Zhang, K., Batterman, S., Dion, F. (2011). Vehicle emissions in congestion: comparison of work zone, rush hour and freeflow conditions. Atmospheric Environment, 45, 1929-1939. https://doi.org/10.1016/j.atmosenv.2011.01.030. 